\title{
Influence of Fashion Involvement, Attitude, and Price, Toward Purchase Intention of Ethnic Weaving
}

\author{
Nadia Saryta Panta ${ }^{1}$, Lena Ellitan ${ }^{2}$, Wahyudi Wibowo ${ }^{3}$ \\ ${ }^{1,2,3}$ Universitas Katolik Widya Mandala Surabaya, Indonesia
}

\begin{abstract}
Ethnic weaving from Indonesia is one of the ethnic fabrics that have very high cultural value. Indeed, ikat weaving is not as popular as batik, but the beauty and cultural philosophy contained in the ikat weaving is not inferior to batik. The weaving industry in Indonesia has long been developed and became a unique characteristic. Ikat weaving has developed in each tribe in Indonesia from generation to generation as an activity to preserve traditional arts. The purpose of this research is to identify and examine the influences of fashion involvement, attitude toward purchasing behavior, price, toward purchase intention of ikat weaving.

The type of research is quantitative and the data collection method used is a questionnaire survey. In this study, data were collected from 125 respondents who are people with an interest in ikat weaving. This study uses PLS-SEM to test the data. This research proved that both attitude toward purchasing behavior and price have positive influences on purchase intention of ikat weaving. Fashion Involvement has a positive influence on attitude toward purchasing behavior. Lastly, attitude toward purchasing behavior has a mediating influence on the relationship between fashion involvement and purchase intention of ikat weaving.
\end{abstract}

KEYWORDS: Attitude Toward Purchasing Behavior, Ethnic Weaving, Fashion Involvement, Price, Purchase Intention.

\section{INTRODUCTION}

Ikat weaving from Indonesia is one of the ethnic fabrics that have very high cultural value. Indeed, ikat weaving is not as popular as batik, but the beauty and cultural philosophy contained in the ikat weaving is not inferior to batik. If Batik has been recognized by UNESCO as one of Indonesia's cultural heritages, the next will be ikat weaving. However, fame of ikat weaving is still inferior when compared to batik as clothing material used by the community. This is due to the difficulty of ikat weavings found in the market and the absence of government intervention in efforts to introduce and preserve ikat weavings to the fullest (Marcute, 2018).

Although not as popular as batik, but the ikat weaving has its uniqueness. The uniqueness of ikat weaving lies in the manufacturing process. To make a beautiful ikat weaving, craftsman weaving takes months. This is because the equipments used for weaving are still using manual techniques. The difficulty of the process of making ikat weaving, causes the availability of ikat weaving in the market is not many and the Price for a piece of ikat weaving is quite expensive so that not everyone can afford it (Marcute, 2018). In contrast to Batik, ikat weaving is made by combining yarn vertically and horizontally, alternately by using techniques that resemble weaving. The yarn used to weave has previously been dyed with a variety of natural colors to form decorative patterns and styles that have a high meaning and philosophy that represent the customs and culture of the local area (Marcute, 2018).

Nusa Tenggara Timur (NTT) is a province in Indonesia which is rich in cultural heritage and natural beauty. The weaving industry in NTT has long been developed and became a unique characteristic of every region in NTT, namely Flores, Sumba, Timor, Rote and Alor. Weaving has developed in each tribe in East Nusa Tenggara from generation to generation as an activity to preserve traditional arts. Weaving is seen as a valuable family property that has high value. In ancient times, ikat weaving was made as ordinary clothing. It then evolves for traditional needs such as traditional ceremonies, dances, weddings, and parties. Today, ikat weaving is commonly used as a shawl, sarong, blanket, to clothing.

The diverse motifs on each sheet of fabric are unique to their stories. This is the main attraction in the eyes of NTT weaving lovers. Products made from weaving have now become a new style in the community, so it is not uncommon to find the use of NTT ikat weaving products at every event, both formal and informal. A large number of NTT weaving enthusiasts makes ordinary people until entrepreneurs compete to create NTT weaving products to attract consumers (Reporter Satuharapan, 2019). 


\section{International Journal of Current Science Research and Review}

ISSN: 2581-8341

Volume 05 Issue 02 February 2022

DOI: 10.47191/ijesrr/V5-i2-16, Impact Factor: 5.825

IJCSRR@ 2022

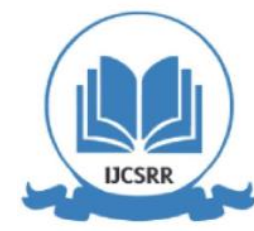

www.ijcsrr.org

This study was motivated by the need to understand the influences of Fashion Involvement, Attitude Toward Purchasing Behavior, and Price toward people's Purchase Intention of NTT ikat weaving. This motivation is arisen since NTT ikat weaving is a traditional clothing which often perceived as outdated in 2020. NTT ikat weaving has to competing with various modern clothing products that attract people who love fashion.

Based on the background, Purchase Intention on fashion product in this paper will be studied around the relationships between Fashion Involvement, Attitude Toward Purchasing Behavior, and Price, that is to follow the previous studies of Amaral (2020) and Lutfiati (2018). The research problems are: (1) Does Attitude Toward Purchasing Behavior have an influence on Purchase Intention of NTT ikat weaving?; (2) Does Price have an influence on Purchase Intention of NTT ikat weaving?; (3) Does Fashion Involvement have an influence on Attitude Toward Purchasing Behavior?; (4) Does Attitude Toward Purchasing Behavior mediates the relationship between Fashion Involvement and Purchase Intention of NTT ikat weaving?

\section{LITERATURE REVIEW}

\section{Purchase Intention}

According to Khuong \& Nguyen (2015), Purchase Intention is described as an individual intention to buy a particular product they have chosen after certain assessments. According to Hosein (2012) the intention to buy a product or brand is one of the cognitive behaviors of customer. Furthermore, according to Vineyard (2014), Purchase Intention is an opportunity to buy product and service. In this sense, Theory of Reasoned Action (TRA) shows that the intention to interact in a behavior precedes a particular behavior. The intention to buy is also a concept of future purchases (Goyal, 2014).

\section{Attitude toward Purchasing Behavior}

According to Byabashaija and Katono (2011) attitude toward behavior is defined as someone's favorable or unfavorable judgment of behavior. Higher the assessment, greater the intention formed. Based on the Theory of Planned Behavior (TPB), better the assessment, better the intention generated later. Thus, Attitude Toward Purchasing Behavior is a person's judgment and belief, both positively and negatively, where later intentions and behavior will be formed and will be evaluated by the individual.

\section{Fashion Involvement}

Customers who are involved in fashion often want to stay abreast of the latest fashion trends. Involvement is a feeling or emotion that is characterized by the interest, enthusiasm and excitement that the buyers compassionate for in some product category. Fashion involvement is a motivational state of passion or interest toward an object that is stimulated by requirements, values, and desires and also the extent to which the object is considered personally relevant (Hakan Celik, 2017).

In clothing marketing, Fashion Involvement refers to the extent of interest in fashion products. Fashion involvement refers to the degree to which an individual is caught up in a number of fashion-related concepts, including awareness, knowledge, interests, and reactions.

\section{Price}

According to Son and Jin (2019) and Phuong (2020), from a consumer perspective, Price is defined as the number of money or total value that a customer actually pays for product or service in exchange for the cumulative benefit from that product or service. Price is the only element of the marketing mix that is flexible which can change at any time. Price also communicates the desired positioning value of the company's product or brand to the market. Price also determines customer loyalty to the brand and influences individual behavior at any time. 


\section{International Journal of Current Science Research and Review}

ISSN: 2581-8341

Volume 05 Issue 02 February 2022

DOI: 10.47191/ijesrr/V5-i2-16, Impact Factor: 5.825

IJCSRR@ 2022

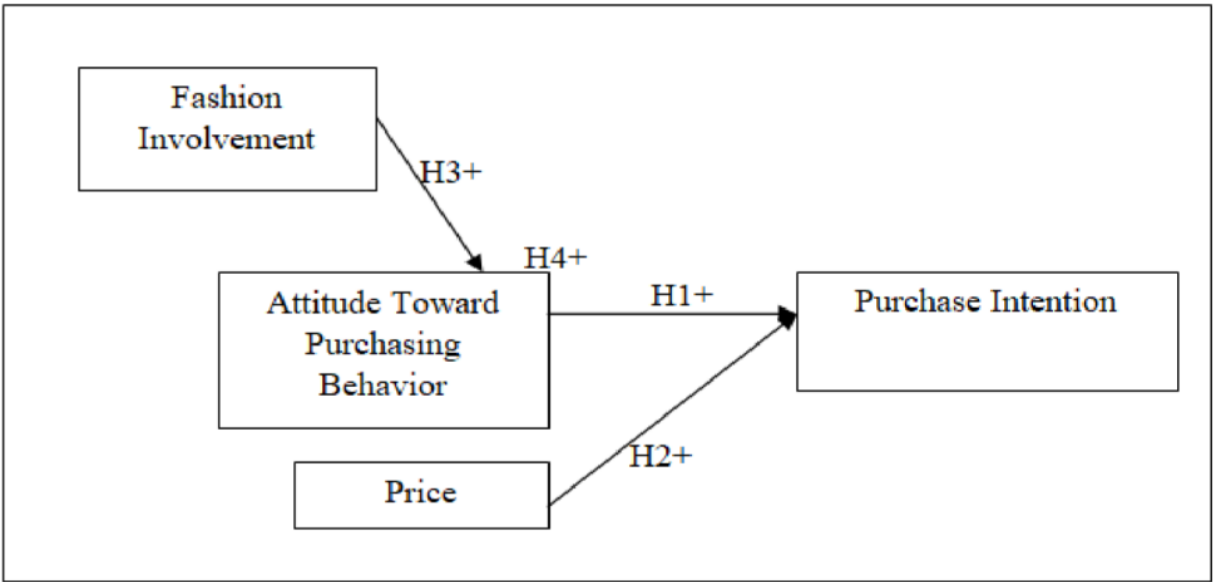

Figure 1. Conceptual Framework

Source: (Amaral, 2020)

\section{Hypothesis development}

In Ajzen (2011) and Chetioui (2020), Purchase Intention is described as a direct function of attitudes, subjective norms and control over behavior, that is consistent with TPB. Attitude toward purchasing behavior prompts an assessment of the individual's likes or dislikes of the selected behavior. This idea shows that the more positive the attitude toward certain behaviors, the stronger the individual's intention to implement it (Chetioui, 2020).

The results of previous research by Amaral (2019) which stated that attitude toward behavior is positively related to the intention to buy NTT ikat weaving for the millennial generation in the city of Kupang. Effects of Attitude Toward Purchasing Behavior toward Purchase Intention can be inconsistent and can vary, due to different factors such as environmental, social, cultural, and others etc. As a result, this paper hypothesizes that:

H1: Attitude Toward Purchasing Behavior has a positive influence on Purchase Intention of NTT ikat weaving.

Price is one of the important variables that influence purchase behavior. This is one of the most helpful factors in determining purchasing behavior. Prices are significantly and positively related to consumer confidence and actual buying behavior, and maximize the results of Price promotions on consumer confidence and actual purchasing behavior (AL-EKAM, 2016). The results of previous research by Nirushan (2017) found that Price have significant impact on Purchase Intention of organic food products. As a result, this paper hypothesizes that:

H2: Price has a positive influence on Purchase Intention of NTT ikat weaving.

According to the study of Sultana (2016) Fashion Involvement involves a person's involvement with a product of clothing because of its needs, interests, and values (Hidayati, 2019). Fashion product is considered a high engagement product that customers tend to look for information from a variety of sources before making a purchase decision because it involves money and is related to the consumer's personal identity. The results of previous research conducted by Farrag (2017) found that Fashion involvement has a positive influence on attitude toward purchasing luxury brands amongst Qatari youth. As a result, this paper hypothesizes that:

H3: Fashion Involvement has a positive influence on Attitude Toward Purchasing Behavior.

The relationship between Fashion Involvement and the NTT ikat weaving is not directly linked to each other in any research article, but there is one journal that deals with this as researchers have discovered. In addition, because the relationship between Fashion involvement and Purchase Intention is always mediated through Attitude Toward Purchasing Behavior in previous studies and has not been tested before, this study will define the relationship between Fashion Involvement and Purchase Intention of NTT ikat weaving and that can also be used in this study. 


\section{International Journal of Current Science Research and Review}

ISSN: 2581-8341

Volume 05 Issue 02 February 2022

DOI: 10.47191/ijesrr/V5-i2-16, Impact Factor: 5.825

IJCSRR@ 2022

Www.ijcsrr.org

The results of previous research by Wulandari (2015) found that the role of mediating attitude of consumer knowledge influence toward Purchase Intention of green product have a positif effect. Suhud, Allan, Wiratama \& Maulida (2020) found that there was a significant influence of Fashion Involvement on ethical Purchase Intention. As a result, this paper hypothesizes that:

H4: Attitude Toward Purchasing Behavior mediates the relationship between Fashion Involvement and Purchase Intention of NTT ikat weaving.

\section{RESEARCH METHOD}

This research utilized quantitative study. The source of data in this research was primary obtained from questionnaire survey via Google form to people with some interest in NTT ikat weaving. The survey used a five-point Likert scale (for ranking one means strongly disagree to rank five means to strongly agree). This research used Structural Equating Modeling (SEM) technique for data analysis, with Partial Least Square (PLS) approach.

\section{Population, Sample, and Sampling Techniques}

This research used a non-probability sampling method with a purposive sampling technique. The population in this research was people with some interest in the fashion product of NTT ikat weaving. Following Hair et al. (2014) for sample measurements to achieve a statistical power of $80 \%$ for detecting R square values of at least 0.10 (with a 5\% probability of error), the sample size of this research was 125 respondents. In term of the characteristics, the respondents were those who have interest in NTT ikat weaving, ever bought NTT ikat weaving, adults with over 20 years old. The distribution of Google form questionnaire was conducted online via social media applications such as WhatsApp, Line, and Instagram.

\section{Variables Identification}

Independent Variables:

$\mathrm{X}_{1}=$ Fashion Involvement

$\mathrm{X}_{2}=$ Price

Dependent Variables:

$\mathrm{Y}_{1}=$ Attitude Toward Purchasing behavior $\mathrm{Y}_{2}=$ Purchase Intention Mediation Variable:

$\mathrm{Y}_{1}=$ Attitude Toward Purchasing Behavior

\section{ANALYSIS AND DISCUSSION}

Respondent Characteristic

Table 1. Characteristics of Respondents

\begin{tabular}{|c|l|c|c|}
\hline \multirow{2}{*}{ Characteristics } & \multirow{2}{*}{ Group } & \multicolumn{2}{|c|}{ Total } \\
\cline { 3 - 4 } & & (person) & (\%) \\
\hline Gender & a. Male & 31 & $24.8 \%$ \\
& b. Female & 94 & $75.2 \%$ \\
& Total & 125 & $100 \%$ \\
\hline Age & a. $20-30$ years old & 56 & $44.8 \%$ \\
& b. 31-40 years old & 36 & $28.8 \%$ \\
& c. $>40$ years old & 33 & $26.4 \%$ \\
& Total & 125 & $100 \%$ \\
\hline Occupation & a. Student & 29 & $23.2 \%$ \\
& b. Employee & 40 & $32 \%$ \\
& c. Entrepreneur & 12 & $9.6 \%$ \\
& d. Other & 44 & $35.2 \%$ \\
& Total & 125 & $100 \%$ \\
\hline
\end{tabular}




\section{International Journal of Current Science Research and Review}

ISSN: 2581-8341

\section{Volume 05 Issue 02 February 2022}

DOI: 10.47191/ijesrr/V5-i2-16, Impact Factor: 5.825

IJCSRR@ 2022

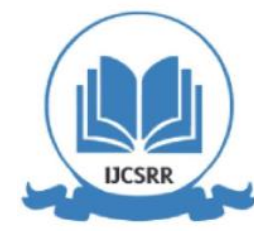

www.ijjcsrr.org

Of the 125 questionnaires, according to gender characteristic, most of the respondents was female (75.2\%) and the male respondents was at 24.8\%. respondents aged 20-30 years old (44.8\%), 31-40 years old (28.8\%), and above 40 years old (26.4\%). Respondents came from a variety of different occupational backgrounds, such as students, civil servants, private workers, and other occupations (housewives, teachers, journalists, excavator operators, photographers, police officers, technicians, and entrepreneurs).

Based on the results in Table 1, respondents with highest interest in NTT ikat weaving were those aged 20-30 years old. It was also found women were more interested in purchasing NTT ikat weaving. This can happen because women are in general more familiar with the use of fashion products such as shoes, clothing, beauty care, and others.

In the following table results from the hypotheses testing are presented.

Table 2. Hypothesis Testing

\begin{tabular}{|c|l|c|c|c|}
\hline Hypothesis & \multicolumn{1}{|c|}{ Path } & T-statistic & $p$-value & Information \\
\hline H1 & ATPB $\rightarrow$ PI & 4.641 & 0.000 & Significant \\
\hline H2 & Price $\rightarrow$ PI & 2.968 & 0.003 & Significant \\
\hline H3 & FI $\rightarrow$ ATPB & 5.197 & 0.000 & Significant \\
\hline H4 & FI $\rightarrow$ ATPB $\rightarrow$ PI & 3.139 & 0.002 & Significant \\
\hline
\end{tabular}

H1: the result of research hypothesis testing between Attitude Toward Purchasing Behavior (y1) and Purchase Intention (y2) produce significant influence, with path coefficient of 0.454 and significant $p$-value of $0.000 \leq 0.5$. Based on this result, it can be concluded that Attitude Toward Purchasing Behavior has positive influence toward Purchase Intention NTT ikat weaving. Therefore, the first hypothesis is accepted.

H2: the result of research hypothesis testing between Price (x2) and Purchase Intention (y2) produce significant influence with path coefficient of 0.463 and significant $p$-value of $0.000 \leq 0.5$. Based on this result, it can be concluded that Price has positive influence toward Purchase Intention of NTT ikat weaving. Therefore, the second hypothesis is accepted.

H3: the result of research hypothesis testing between Fashion Involvement (x1) and Attitude Toward Purchasing Behavior (y1) produce significant influence with path coefficient of 0.463 and significant p-value of $0.000 \leq 0.5$. Based on this result, it can be concluded that Fashion Involvement has positive influence toward Attitude Toward Purchasing Behavior. Therefore, the third hypothesis is accepted.

H4: the result of research hypothesis testing between Fashion Involvement (x1) and Purchase Intention (y2) produce significant influence with path coefficient of 0.210 and significant $\mathrm{p}$-value of $0.002 \leq 0.5$. Based on this result, it can be concluded that Fashion Involvement has positive relationship toward Purchase Intention of NTT ikat weaving in which Attitude Toward Purchasing Behavior acts as an intermediary for the influence. Therefore, the fourth hypothesis is accepted.

The results of this research shown that all of the four proposed hypotheses are accepted. Further explanations about the hypothesis are given in the following. The influence of Attitude Toward Purchasing Behavior on Purchase Intention is positive, means higher level of Attitude Toward Purchasing Behavior will increase customers' intention to purchase NTT ikat weaving. NTT ikat weaving has their own uniqueness that can attract customer to buy it. Consumers feel confident when wearing clothes or accessories which is derived from NTT ikat weaving and give a different impression on the appearance of NTT ikat weaving users compared to others. This result is in accordance with the previous research by Amaral (2020).

Next, the influence of Price on Purchase Intention is positive. Price is regarded as a factor that can influence customer intention to purchase NTT ikat weaving. It shows that consumers tend not to think about how expensive is the price when buying NTT ikat weaving, because they think the quality of NTT ikat weaving is comparable with the price. Hence, Price here is considered to have a positive role. If it is a signal for positive product attributes, such as quality, then higher Price has a positive effect on purchasing behavior. 


\section{International Journal of Current Science Research and Review}

ISSN: 2581-8341

Volume 05 Issue 02 February 2022

DOI: 10.47191/ijesrr/V5-i2-16, Impact Factor: 5.825

IJCSRR@ 2022

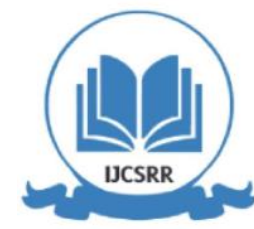

www.ijcsrr.org

Consumers of NTT ikat weaving are more concerned with the quality of weaving. Consumers accepted that better quality of weaving, more motifs, and more complicated work techniques, means higher price for NTT ikat weaving. In other words, consumers think NTT ikat weaving is something of value that is worth to buy. This research results is in accordance with the previous research by Lutfiati (2018). The research shows that Price has a positive effect on consumer interest in NTT ikat weaving in Sentra Ina Ndao, Kupang City.

The influence of Fashion Involvement on Attitude Toward Purchasing Behavior is positive. Higher level of Fashion Involvement will support higher level of Attitude Toward Purchasing Behavior of NTT ikat weaving. Higher consumer interest in fashion are associated with higher preference to buy NTT ikat weaving. This is due to the attractive motifs of NTT ikat weaving. Moreover, consumers feel that buying NTT ikat weaving as a fashion item is a right choice because of its uniqueness. This result is in accordance with the previous research by Farrag (2017). The research shows that Attitude Toward Purchasing Behavior has positively associated with the Purchase Intention of luxury brands among the Qatari youths.

The role of Attitude Toward Purchasing Behavior in mediating the influence of Fashion Involvement toward Purchase Intention is proven. Consumers are influenced by Fashion Involvement in making the decision to buy NTT ikat weaving, with the information that has been obtained and after some consideration consumers will purchase NTT ikat weaving. In this regard, the relationship between Fashion Involvement and Purchase Intention must pass through the mediating role of Attitude Toward Purchasing Behavior. This result is in accordance with the previous research by Hashmi et al. (2016).

\section{CONCLUSION AND LIMITATION}

Purchase intention is the sum total of cognitive, affective and behavioral towards adoption, purchase, and use of the product, services, ideas or certain behaviors. In this study, there are three independent variables namely Fashion Involvement, Price, and Attitude Toward Purchasing Behavior. This research was conducted to determine whether these three variables have an influence on consumer Purchase Intention, with also testing whether Attitude Toward Purchasing Behavior acts as a mediator.

The purpose of this research is to identify and examine the positive impact of Influence of Fashion Involvement, Attitude Toward Purchasing Behavior, Price, Toward Purchase Intention of NTT ikat weaving. In this case, Attitude Toward Purchasing Behavior acts as a mediating variable.

The results concluded that Attitude Toward Purchasing Behavior is proven to have a significant and positive influence on Purchase Intention. The better the assessment, the better the intention generated later. In the second conclusion, it can be drawn that Price is proven to have a significant and positive influence on Purchase Intention. In this sense, Price acts as a signal for positive product attributes.

The third conclusion, Fashion Involvement is proven to have a significant and positive effect on Attitude Toward Purchasing Behavior. Customers who are often involved in fashion want to stay abreast of the latest fashion trends. moreover, the fourth conclusion can be drawn that Fashion Involvement is proven to have a significant and positive effect on Purchase Intention through Attitude Toward Purchasing Behavior. Attitude Toward Purchasing Behavior can positively mediate the effect of Fashion Involvement on Purchase Intention. If Fashion Involvement is linked directly to Purchase Intention the results remain significant. The respondent's response on Fashion Involvement can determine the level of Purchase Intention.

For the next researches, it is suggested to add more exogenous variables, also to increase the number of the respondents. For practitioners in the field, craftsmen and sellers of NTT ikat weaving need to pay attention to the factor of Fashion Involvement in increasing the product sales by adjusting the design of motifs and colors in order to be applied or used for various fashion products. Maintenance and improvement of the product quality are also highly suggested. The innovations should not be too excessive so as not to eliminate the authenticity of the ikat weaving motif. NTT ikat weaving makers should be able to see the growing trends in society in order to create products with unique designs.

\section{REFERENCES}

1. Agwu, D. F. (2014). a Review of the Effect of Pricing Strategies on the Purchase of Consumer Goods. International Journal of Research in Management, Science \& Technology, 2 (2), 88-102.

2. AL-EKAM, J. M. (2016). The Mediating Effect of Brand Trust on The Influence of Communication, Price, and Product quality on Consumer Purchase Behaviour In a Less-Developed Country. Malaysian Management Journal. 


\section{International Journal of Current Science Research and Review}

ISSN: 2581-8341

Volume 05 Issue 02 February 2022

DOI: 10.47191/ijesrr/V5-i2-16, Impact Factor: 5.825

IJCSRR@ 2022

www.ijcsrr.org

3. Amaral, M. A. (2020). Millennial Generation Purchasing Behavior in Kupang: Tenun Ikat NTT, 59.

4. Amaral, M. A. (2020). Millennial Generation Purchasing Behavior in Kupang: Tenun Ikat NTT.

5. Anaboeni, F. J. (2017). Peran Pemerintah Nusa Tenggara Timur Dan Kelompok Ina

6. Ndao Dalam Meningkatkan Kinerja Produksi Ikm Tenun Ikat Mira Keddi . EKOBIS - Ekonomi Bisnis .

7. Arikunto., S. (2010). Prosedur Penelitian Suatu Pendekatan Praktik.

8. Budiyanti, S. P. (2016). The Theory of Planned Behavior, Past Behavior, Situational Factors, and Self-Identity Factors Drive Indonesian Entrepreneurs to be Indebtedness. DeReMa Jurnal Manajemen. Vol 11. No. 1. .

9. Celil Koparal, N. Ç. (2015). International Journal of Social Sciences Vol. IV (1). Hedonic Consumption Characteristics Related to Products and Services where Fashion Involvement Plays an Important Role, A Field Study from Eskisehir, Turkey .

10. Chetioui, Y. H. B. (2020). How fashion influencers contribute to consumers' Purchase Intention. Journal of Fashion Marketing and Management: An International Journal.

11. Dr. Maria Merry Marianti \& Istiharini, S. (2013). Analysis of Consumer Characteristics and Behavior. Analysis of Consumer Characteristics and Behavior.

12. Dr. Vahidreza Mirabi, H. A. (2015). A Study of Factors Affecting on Customers Purchase Intention Case Study: the Agencies of Bono Brand Tile in Tehran. Journal of Multidisciplinary Engineering Science and Technology (JMEST) .

13. E. B. Setiawan, D. K. (2016). Impact of Price Fairness on Brand Image and Purcase Intention for Low Cost Car in Indonesia. International Journal of Economics Commerce and Management, 4(9), 300-308.

14. Farrag, D. A. (2017). The Young Luxury Consumer in Qatar. Young Consumers .

15. Fauziah, S. (2016, Maret 19). From the tip of Aceh to Papua, the motifs and colors also vary.

16. Ghina, L. T. (2016). Identification of Attitude toward Behavior, Subjective Norm, and Perceived Behavioral Control as a Push Factor of Become Entrepreneurship (Studi of Entrepreneur with Last Education Status Senior High School). eProceeding of Management : Vol.3, No.2 .

17. Ghozali, H. L. (2015). Partial least squares: Konsep,teknik, dan aplikasi menggunakan program smart PLS 3.0 (2 ${ }^{\text {nd }}$ ed.). Semarang: Universitas Dipone-goro Semarang.

18. Goyal, R. (2014). Purchase Intentions of Consumers toward Selected Luxury Fashion Products with special reference to Pune Region. Navi Mumbai: DY Patil University.

19. Hair, J. F. (2014). A Primer on Partial Least Squares Structural Equation Modelling (PLS-SEM). United States of America: SAGE Publication Inc.

20. Hakan Celik, R. K. (2017). Roles of Self-Monitoring, Fashion Involvement and Technology Readiness in an Individual's Propensity to Use Mobile Shopping . Journal of Systems and Information Technology.

21. Hendriawan, L. T. (2016). Identification of Attitude Toward Behavior, Subjective Norm, and Perceived Behavioral Control as a Push Factor of Become Entrepreneurship (Studi of Entrepreneur with Last Education Status Senior High School). $e$ Proceeding of Management.

22. Hidayati, V. A. (2019). Self-control Student of Maulana Malik Ibrahim State Islamic University Malang Viewed from Fashion Involvement. Journal of Islamic Psychology and Psychology (JPPI) .

23. Hosein, N. Z. (2012). Measuring the Purchase Intention of visitors to the auto show. . Journal of Management \& Marketing Research, 9, 1-17.

24. Jin, J. S. (2019). When do high Prices lead to Purchase Intention? Testing two layers of moderation effects. Asia Pacific Journal of Marketing and Logistics.

25. Kapoor, A. M. (2019). Self-consciousness and emotions driving femvertising: A path analysis of women's attitude toward femvertising, forwarding intention and Purchase Intention. Journal of Marketing Communications.

26. Katono., W. B. (2011). The Impact of College Entrepreneurial Education on Entrepreneurial Attitudes and Intentions to Start a Business in Uganda. Journal of Developmental Entrepreneurship, 16, 127-144.

27. Khan, M. A. (2020). The Influence of Shopping Motivation on Fashion Retailers, with Mediating Role of Fashion Innovativeness and Fashion Consciousness. European Journal of Management and Marketing Studies.

28. Kupang.tribunnews.com. Guru Besar UI Puji Tenun Ikat NTT. Obtained from 


\section{International Journal of Current Science Research and Review}

ISSN: 2581-8341

Volume 05 Issue 02 February 2022

DOI: 10.47191/ijesrr/V5-i2-16, Impact Factor: 5.825

IJCSRR@ 2022

Www.ijcsrr.org

https://kupang.tribunnews.com/2016/08/30/guru-besar-ui-puji-tenun-ikatntt, 6 July 2020, at 00:46 a.m

29. Lutfiati, Y. F. (2018). Consumer Interest in NTT Ikat Weaving in Sentra Ikat Ika in Ndao.

30. Marcute. (2018, March 25 ). Get Closer to Kinds of Kinds of Weaving Tools.

31. Multazami, S. N. (2016). Pengaruh Shopping Lifestyle dan Fashion Involvement terhadap Impulsive Buying Behavior Masyarakat Kota Makassar.

32. Nabila Ansari, S. K. (2019). Sustainability and quality as an indicator of consumer attitude toward the green product. Vol67 .

33. Nguyen, M. N. (2015). The effects of television commercials on customers Purchase Intention-a study of milk industry in Ho Chi Minh City, Vietnam. . Journal of Economics, Business and Management, Vol. 3, No. 9.

34. Nirushan, K. (2017). The Impact of Price and Trust on Purchase Intention of Organic Food Products in Trincomalee District. International Journal of Research in Management \& Business Studies (IJRMBS 2017) Vol. 4 Issue 3 .

35. Patricia, R. D. (2018). Effect of Behavior Attitude, Perceived Behavioral Control, and Subjective Norm on Entrepreneurial Intention of Non-Economic Students. Economy and Business .

36. Phuong, T. T. (2020). An Empirical Study Examining a Mediated Moderated Model of Perceived Price Fairness, Brand Equity and Purchase Intention. International Journal of Advanced Research in Economics and Finance .

37. Reporter Satuharapan. (2019, Oktober 31). Creating NTT Weaving in Handicraft Products. Creating NTT Weaving in Handicraft Products .

38. Ryu, S. V. (2018). Celebrity fashion brand endorsement in Facebook viral marketing and social commerce Interactive effects of social identification, materialism, Fashion Involvement, and opinion leadership. Journal of Fashion Marketing and Management

39. Shah, H. A. (2012). The Impact of Brands on Consumer Purchase Intentions. Asian Journal of Business Management 4(2): 105-110.

40. Shih Chien, H. R. (2011). The influences of perceived value on consumer Purchase Intention: the moderating effect of advertising endorser. Journal of International Management Studies, 6(1), 1-6.

41. Solomon, M. R. (2014). Consumer behavior: Buying, having, and being. Englewood

42. Cliffs, NJ: Prentice.

43. Sugiharto, E. J. (2011). Pengaruh Shopping Lifestyle dan Fashion Involvement Terhadap Impulsive Buying Behavior Masyarakat High Income Surabaya. Jurnal Manajemen Pemasaran, Vol. 06.

44. Sugiharto, E. J. (2011). The Effect of Shopping Life Style and Fashion Involvement. Journal of Marketing Management .

45. Sugiyono. (2012). Metode Penelitian Kuantitatif Kualitatif dan R\&B. Bandung: Alfabeta.

46. Sugiyono. (2013). Metode Penelitian Pendidikan Pendekatan Kuantitatif, Kualitatif, dan R\&D. Bandung: Alfabeta.

47. Sugiyono. (2014). Metode Penelitian Pendidikan Pendekatan Kuantitatif. Bandung: Alfabeta.

48. Suprapti, N. S. (2010). Perilaku Konsumen Pemahaman Dasar dan Aplikasinya Dalam Strategi Pemasaran. . Denpasar: Udayana Univiversity Press.

49. Tempo.co. (2010, December 2). Three Types of Weaving in East Nusa Tenggara.

50. Tryanti, R. H. (2018). Influence of Fashion Involvement and Shopping Impulsive Purchasing on Student Lifestyle. Journal of Applied Business Administration .

51. Tsalis, G. (2020). What's the deal? Consumer Price involvement and the intention to purchase suboptimal foods. Acrossnational study. Food Quality and Preference.

52. Usep Suhud, M. A. (2020). Slow Fashion in Indonesia: Drivers and Outcomes of Slow Fashion Orientations. Research in World Economy.

53. Vineyard, C. L. (2014). The relationship between fashion blogs and intention to purchase and word of mouth behavior. Textiles, Merchandising and Fashion Design: Dissertations, Theses, \& Student Research. Paper 4.

54. Weiner, H. E. (2017). Wearing your Ethics: Investigating Consumer Purchase Intention of Ethically Produced Fashion Products. Theses and Dissertations .

55. Wulandari, A. S. (2015). The Role of Customer Attitude In Mediating Knowledge Influence Toward The Purchase Intention of Green Product. Jurnal Dinamika Manajemen JDM Vol. 6, No. 2, 2015, pp: 133-144 . 


\section{International Journal of Current Science Research and Review}

ISSN: 2581-8341

Volume 05 Issue 02 February 2022

DOI: 10.47191/ijesrr/V5-i2-16, Impact Factor: 5.825

IJCSRR@ 2022

\section{APPENDIX}

Table A. Descriptive Statistics about Respondents' Response on Fashion

Involvement

\begin{tabular}{|c|c|c|c|}
\hline Indicator & Mean & Std. Deviation & Information \\
\hline $\begin{array}{l}\text { I use NTT ikat weaving as } \\
\text { material for clothes or } \\
\text { accessories }\left(\mathrm{X}_{1.1}\right)\end{array}$ & 4.58 & 0.6752 & Strongly Agree \\
\hline $\begin{array}{l}\text { I feel confident when wearing } \\
\text { clothes or accessories which } \\
\text { is derived from NTT ikat } \\
\text { weaving }\left(\mathrm{X}_{1,2}\right)\end{array}$ & 4.77 & 0.4941 & Strongly Agree \\
\hline $\begin{array}{l}\text { I wear NTT ikat weaving to } \\
\text { distinguish my appearance } \\
\text { from others }\left(\mathrm{X}_{1,3}\right)\end{array}$ & 4.16 & 1.0806 & Agree \\
\hline $\begin{array}{l}\text { I keep up with the } \\
\text { development of information } \\
\text { about NTT ikat weaving } \\
\left(\mathrm{X}_{1.4}\right)\end{array}$ & 3.98 & 1.0431 & Agree \\
\hline $\begin{array}{l}\text { I continue to follow the latest } \\
\text { designs of clothes or } \\
\text { accessories made from NTT } \\
\text { ikat weaving }\left(X_{1.5}\right)\end{array}$ & 3,96 & 1.0503 & Agree \\
\hline Fashion Involvement $\left(\mathrm{X}_{1}\right)$ & 4.29 & 0.8687 & Strongly Agree \\
\hline
\end{tabular}

Table B. Descriptive Statistics about Respondents' Response on Price

\begin{tabular}{|l|c|c|c|}
\hline \multicolumn{1}{|c|}{ Indicator } & Mean & Std. Deviation & Information \\
\hline $\begin{array}{l}\text { I would argue that the price } \\
\text { needs to be considered when } \\
\text { I am going to buy NTT ikat } \\
\text { weaving }\left(\mathrm{X}_{2.1}\right)\end{array}$ & 3.80 & 1.0526 & Agree \\
\hline $\begin{array}{l}\text { I have more concerned with } \\
\text { the quality than the price } \\
\text { when buying NTT ikat } \\
\text { weaving }\left(\mathrm{X}_{2.2}\right)\end{array}$ & 4.43 & 0.7442 & Strongly Agree \\
\hline $\begin{array}{l}\text { I think the more expensive } \\
\text { the price of NTT ikat } \\
\text { weaving, the better overall } \\
\text { quality of the fabric, motifs, } \\
\text { also with more complicated } \\
\text { workmanship techniques } \\
\left(\mathrm{X}_{2.3}\right)\end{array}$ & 4.65 & 0.6630 & Strongly Agree \\
\hline Price $\left(\mathrm{X}_{2}\right)$ & 4.29 & 0.8199 & Strongly Agree \\
\hline
\end{tabular}




\section{International Journal of Current Science Research and Review}

ISSN: 2581-8341

Volume 05 Issue 02 February 2022

DOI: 10.47191/ijesrr/V5-i2-16, Impact Factor: 5.825

IJCSRR@ 2022

Table C. Descriptive Statistics about Respondents’ Response on Attitude

Toward Purchasing Behavior

\begin{tabular}{|c|c|c|c|}
\hline Indicator & Mean & $\begin{array}{c}\text { Std. } \\
\text { Deviation }\end{array}$ & Information \\
\hline $\begin{array}{l}\text { I feel that NTT ikat weaving } \\
\text { are worth buying }\left(\mathrm{Y}_{t .1}\right)\end{array}$ & 4.78 & 0.6548 & Strongly Agree \\
\hline $\begin{array}{l}\text { I feel that NTT ikat weaving } \\
\text { have an interesting motif to } \\
\text { buy }\left(\mathrm{Y}_{1,2}\right)\end{array}$ & 4,90 & 0.3318 & Strongly Agree \\
\hline $\begin{array}{l}\text { I have a good feeling in } \\
\text { buying NTT ikat weaving as } \\
\text { a fashion item }\left(\mathrm{Y}_{1,3}\right)\end{array}$ & 4.80 & 0.4752 & Strongly Agree \\
\hline $\begin{array}{l}\text { I feel that buying NTT ikat } \\
\text { weaving is a good decision } \\
\left(\mathrm{Y}_{1,4}\right)\end{array}$ & 4.62 & 0.5773 & Strongly Agree \\
\hline $\begin{array}{c}\text { Attitude Toward Purchasing } \\
\text { Behavior }\left(\mathrm{Y}_{1}\right)\end{array}$ & 4.77 & 0.5098 & Strongly Agree \\
\hline
\end{tabular}

Table D. Descriptive Statistics about Respondents' Response on Purchase Intention

\begin{tabular}{|c|c|c|c|}
\hline Indicator & Mean & $\begin{array}{l}\text { Std. } \\
\text { Deviation }\end{array}$ & Information \\
\hline $\begin{array}{l}\text { I am interested to buy NTT } \\
\text { ikat weaving after getting } \\
\text { relevant information }\left(\mathrm{Y}_{2.1}\right)\end{array}$ & 4.20 & 0.9333 & Strongly Agree \\
\hline $\begin{array}{l}\text { I will buy NTT ikat weaving } \\
\text { after getting reviews and } \\
\text { recommendations }\left(\mathrm{Y}_{2.2}\right)\end{array}$ & 3.74 & 1.1137 & Agree \\
\hline $\begin{array}{l}\text { I will buy more NTT ikat } \\
\text { weaving }\left(\mathrm{Y}_{23}\right)\end{array}$ & 4.60 & 0.6956 & Strongly Agree \\
\hline $\begin{array}{l}\text { I would recommend my family } \\
\text { and friends to buy NTT ikat } \\
\text { weaving }\left(\mathrm{Y}_{2.4}\right)\end{array}$ & 4.71 & 0.5208 & Strongly Agree \\
\hline Purchase Intention $\left(\mathrm{Y}_{2}\right)$ & 4.31 & 0.8159 & Strongly Agree \\
\hline
\end{tabular}

Table E. Indirect Effect Value

\begin{tabular}{||l|c|c|c|c|c|c||}
\hline & $\begin{array}{c}\text { Original } \\
\text { Sample } \\
(\mathbf{O})\end{array}$ & $\begin{array}{c}\text { Sample } \\
\text { Mean } \\
(\mathbf{M})\end{array}$ & $\begin{array}{c}\text { Standard } \\
\text { Deviation } \\
\text { (STDEV) }\end{array}$ & $\begin{array}{c}\text { T Statistics } \\
(\mid \mathbf{O} / \text { STDEV } \mid\end{array}$ & $\begin{array}{c}\text { P } \\
\text { Values }\end{array}$ & $\begin{array}{c}\text { Informatio } \\
\mathbf{n}\end{array}$ \\
\hline $\begin{array}{l}\text { ATPB } \\
\text { (Y1) }> \\
\text { PI (Y2) }\end{array}$ & 0.454 & 0.458 & 0.092 & 4.953 & 0.000 & Significant \\
\hline $\begin{array}{l}\text { FI (X1) } \\
\text { > } \\
\text { ATPB } \\
\text { (Y1) }\end{array}$ & 0.463 & 0.490 & 0.092 & 5.036 & 0.000 & Significant \\
\hline $\begin{array}{l}\text { Price } \\
\text { (X2)> } \\
\text { PI(Y2) }\end{array}$ & 0.323 & 0.334 & 0.105 & 3.072 & 0.002 & Significant \\
\hline
\end{tabular}


International Journal of Current Science Research and Review

ISSN: 2581-8341

Volume 05 Issue 02 February 2022

DOI: 10.47191/ijcsrr/V5-i2-16, Impact Factor: 5.825

IJCSRR@ 2022

www.ijcsrr.org

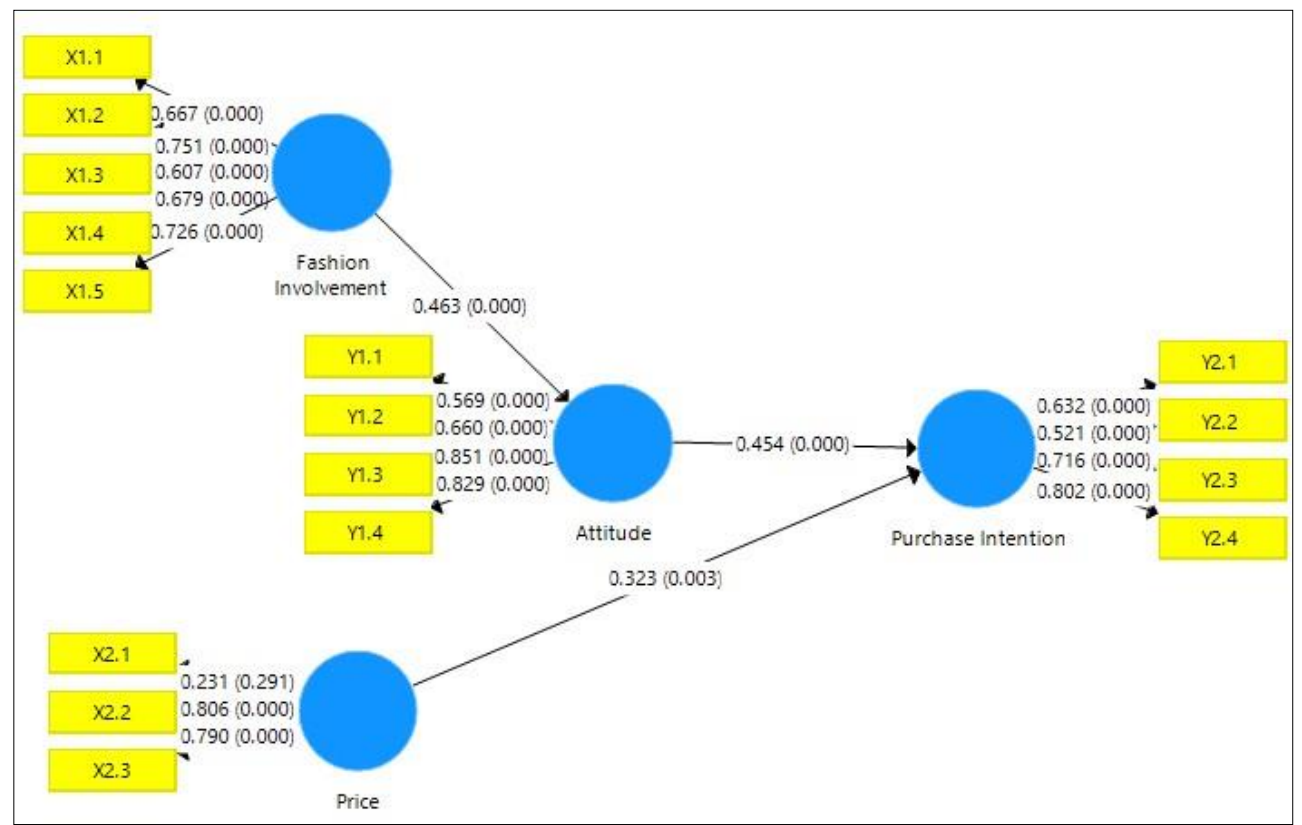

Figure A. Path Modeling using SMART PLS 3.2

Cite this Article: Nadia Saryta Panta, Lena Ellitan, Wahyudi Wibowo (2022). Influence of Fashion Involvement, Attitude, and Price, Toward Purchase Intention of Ethnic Weaving. International Journal of Current Science Research and Review, 5(2), 424-434 